\title{
A SCALABLE SALIVA-BASED, EXTRACTION-FREE RT-LAMP PROTOCOL FOR SARS-COV-2 DIAGNOSIS
}

Paula Asprino, Ph.D. ${ }^{2}$, Fabiana Bettoni, Ph.D. ${ }^{2}$, Anamaria Camargo, Ph.D. ${ }^{2}$, Diego Coelho, Ph.D. ${ }^{1}$, Guilherme Coppini ${ }^{1}$, Igor Correa ${ }^{1}$, Erika Freitas, Ph.D. ${ }^{1}$, Lilian Inoue, Ph.D. ${ }^{2}$, João Paulo Kitajima, Ph.D. ${ }^{1}$, Mayra Kuroki, M.S. ${ }^{2}$, Cibele Masotti, Ph.D. ${ }^{2}$, Tatiana Marques, M.S. ${ }^{2}$, Alice Reis ${ }^{2}$, Luiz Fernando Reis, Ph.D. ${ }^{2}$, Bibiana Santos, Ernande dos Santos, M.S. ${ }^{1}$, David Schlesinger, M.D., Ph.D. ${ }^{1}$, Cecília Sena ${ }^{1}$, Talita Spadaccini ${ }^{1}$, Lucas Taniguti, M.S. ${ }^{1}$

\section{Institutions :}

1. Mendelics Análise Genômica, São Paulo, Brazil

2. Hospital Sírio-Libanês, São Paulo, Brazil

* Authors listed in alphabetical order.

** Correspondence should be sent to David Schlesinger (david@mendelics.com) and Anamaria Camargo (aacamargo@mochsl.org.br).

\section{ABSTRACT}

Scalable, cost-effective screening methods are an essential tool to control SARS-CoV-2 spread. We have developed a straight saliva-based, RNA extraction-free, RT-LAMP test that is comparable to current nasopharyngeal swab RT-PCR tests in both sensitivity and specificity. Using a 2-step readout of fluorescence and melting-point curve analysis, the test is scalable to more than 30,000 tests per day with average turnaround time of less than 3 hours. The test was validated using samples from 244 symptomatic patients, and showed sensitivity of $78.9 \%$ (VS. $85.5 \%$ for nasopharyngeal swabs RT-PCR) and specificity of $100 \%$ (vs. $100 \%$ for nasopharyngeal swabs RT-PCR). Our method is therefore accurate, robust, time and cost effective and therefore can be used for screening of SARS-COV-2. 


\section{INTRODUCTION}

The corona virus disease 2019 (COVID-19) caused by the SARS-CoV-2 (Severe acute respiratory syndrome coronavirus 2) has become a major public health emergency worldwide. Accurate diagnosis of COVID-19 is crucial to control disease transmission and manage infected patients.

Reverse transcription followed by real-time Polymerase chain reaction (RT-PCR) assays using RNA extracted from nasopharyngeal swabs are the gold standard for SARS-CoV-2 molecular diagnostic and are currently the screening strategy used worldwide. These methods are cost and labor-intensive, including several steps that require sample handling, and have been restrained by lack of real-time PCR-specific instruments and reagents.

Sample collection through nasopharyngeal swabs itself is also a major barrier to high-scale, low-cost testing due to limited availability of swabs and necessity of a trained professional, themselves at risk for infection. In this context, saliva has emerged as a viable non-invasive alternative for viral detection, showing comparable viral loads for SARS-CoV-2 in infected patients. (Anne L. Wyllie et al. 2020; Anne Louise Wyllie et al. 2020). Saliva auto-collection is an enticing proposition that simplifies sample collection logistics and reduces infection risk of healthcare workers.

RNA extraction is another important bottleneck for COVID-19 diagnosis. Supply of reagents and automation hardware are limited and incompatible with the worldwide demand. Single-step RNA extraction solutions increase sensitivity but add complexity and cost to the process.

In 2000, Notomi et al. developed a DNA amplification method based on an isothermal reaction: Loop-mediated isothermal amplification (LAMP). (Notomi et al. 2000) LAMP is faster than PCR, utilizes a different DNA polymerase, and can be read out through multiple methods, ranging from simple colorimetric (Zhang et al. 2020), to direct fluorescence (Lu et al. 2020), Crispr-based assays (Joung et al. 2020), and sequencing (James et al., n.d.). LAMP methodology has been used for diagnosis of influenza virus (Poon et al. 
medRxiv preprint doi: https://doi.org/10.1101/2020.10.27.20220541; this version posted October 27, 2020. The copyright holder for this preprint (which was not certified by peer review) is the author/funder, who has granted medRxiv a license to display the preprint in perpetuity.

It is made available under a CC-BY-NC-ND 4.0 International license .

2005), Ebola virus (Kurosaki, Magassouba, and Oloniniyi 2016), and a variety of other pathogens (Bartolone et al. 2018).

Several groups have published LAMP protocols for SARS-CoV-2 diagnosis, including FDA-approved protocols. However, the majority of these protocols are based on direct nasopharyngeal swab samples followed by RNA extraction which are still associated with some limitations, as has been discussed previously.

To contribute towards solutions for Covid-19 diagnosis, we combined and optimized previously published protocols to establish a simplified, saliva-based, RNA extraction-free RT-LAMP test that centralized labs can execute at large-scale population levels.(Lalli, Langmade, et al. 2020) By focusing on simplicity as the primary goal, we have added to this body of scientific literature by creating a test that is cheap, fast, scalable, and accurate.

\section{MATERIALS AND METHODS}

\section{A. Subjects}

IRB approval (HSL 2020-43) was obtained prior to clinical studies. Subjects included in the study presented to the Hospital Sírio-Libanês in São Paulo, Brazil with 1-7 days of symptoms suggestive of Covid-19. All subjects were diagnosed by routine nasopharyngeal swab RT-PCR collected at the same time as the saliva samples.

\section{B. Sample Collection}

Saliva samples were collected by patients themselves in sterile $50 \mathrm{ml}$ conical tubes with no additives. Approximately $1 \mathrm{ml}$ of saliva was collected and the pre-collection instruction was to refrain from eating, drinking or smoking for 60 minutes. Samples were then stored at room temperature for a period ranging from 1 to 3 days.

\section{RT-LAMP}

The RNA-extraction free protocol for RT-LAMP was adapted from (Lalli, Chen, et al. 2020; Lamb et al. 2020). Saliva aliquots (50 ul) were pre-heated at 
medRxiv preprint doi: https://doi.org/10.1101/2020.10.27.20220541; this version posted October 27, 2020. The copyright holder for this preprint (which was not certified by peer review) is the author/funder, who has granted medRxiv a license to display the preprint in perpetuity.

It is made available under a CC-BY-NC-ND 4.0 International license .

$980 \mathrm{C}$ for 10 minutes to release RNA from cells and 8 ul of the supernatant were transferred to $42 \mathrm{ul}$ of RT-LAMP reaction mix. The reaction was incubated for 5 minutes at room temperature, for Uracil-DNA-Glycosylase (UDG) to eliminate eventual carryover contaminants. Using a conventional thermocycler, RT-LAMP reaction (table 1 ) was heated to $630 \mathrm{C}$ for 30 minutes and then reaction was stopped by heating to $800 \mathrm{C}$ for an additional 5 minutes. Primer set (table 3 ) consists of six primers designed by Joung and colleagues. (Joung et al. 2020) to target the Nucleocapsid gene, which has higher copy numbers than other segments of the SARS-CoV-2 genome. Synthetic SARS-CoV-2 RNA from Twist Biosciences was used as positive control and nuclease-free water and saliva from healthysubjects as negative controls.

\section{RT-LAMP Readout}

RT-LAMP products were diluted 40x with EvaGreen fluorescent dye (CellCo, 100x diluted in TAE1X) and read in a fluorescence spectrophotometer. RT-LAMP products from positive samples were also analyzed by Agilent 2100 Bioanalyzer and real time PCR equipment.

Readings in the fluorescence spectrophotometer (Promega Glomax) were considered negative if the diluted reaction had less than $1500 \mathrm{RFU} / \mathrm{ul}$. The fluorescence in each well was measured once, with excitation modules and emission at $475 \mathrm{~nm}$ and $500-550 \mathrm{~nm}$ respectively.

Resulting RT-LAMP products were also analyzed using Bioanalyzer, for characteristic banding patterns (Lamb et al. 2020) and confirmed by dissociation curve analysis in a real time PCR equipment (CFX96 Touch Real-Time PCR Thermal Cycler Biorad or 7300-Applied Biosystems), using cycling parameters as follows: $63^{\circ} \mathrm{C}$ for $1: 00 \mathrm{~min}, 95^{\circ} \mathrm{C}$ for 15 seconds, melt analysis performed from $63^{\circ} \mathrm{C}$ to $95^{\circ} \mathrm{C}$, in a method broadly similar to (Rolando et al. 2020). The incorporation of dissociation curves allows the confirmation of low viral load positives from negatives samples, as well as increases the specificity for SARS-CoV-2 detection. 


\section{RESULTS}

\section{A. ANALYTICAL SENSITIVITY}

RT-LAMP analytical sensitivity was determined by limiting dilution of synthetic SARS-CoV-2 RNA (Twist Bioscience). Ten replicates of six different concentrations ranging from 10,000 copies to 10 copies per reaction were processed through the assay. Limit of detection (LOD) was defined as the lowest concentration at which $>90 \%$ of the replicates were detected. LoD was determined as 20 copies per reaction (cutoff $-d(R F U) / d T=20)$. (Figure 1 ). Considering the use of $8 \mu l$ of saliva as input, the estimated detection limit is 2.5 copies per $\mu l$.

\section{B. REPLICABILITY}

Inter-plate replicability was determined using 122 consecutive plates containing 1 positive control and 1 negative control. (Figure 2). All 122 positive controls scored above the 1,900 RFU stringent cutoff (minimum positive control value $=2,066 \mathrm{RFU})$. All 122 negative controls scored below the more sensitive cutoff of 1,500 used for subsequent melting point evaluation (maximum negative control value $=817 \mathrm{RFU}$ ). In Figure 3, 50,000 consecutive samples, positive and negative subjects show a similar fluorescence readout distribution to corresponding controls.

\section{CLINICAL PERFORMANCE}

Saliva RT-LAMP results were compared to nasopharyngeal RT-PCR results from an independent lab. Validation was independently carried out by Mendelics and Hospital Sírio-Libanês, and the results were combined. RT-LAMP and RT-PCR results were blinded to the complementary results.

As shown in Table 4, a total of 244 symptomatic patients, ranging from days 1 through 7 of symptoms, were tested. SARS-CoV-2 RNA was detected in $31 \%$ $(76 / 244)$ of patients by at least one method. RT-PCR identified 65 of 76 patients (sensitivity of $85.5 \%$ ) while RT-LAMP identified 60 of 76 patients 
medRxiv preprint doi: https://doi.org/10.1101/2020.10.27.20220541; this version posted October 27, 2020. The copyright holder for this preprint (which was not certified by peer review) is the author/funder, who has granted medRxiv a license to display the preprint in perpetuity. It is made available under a CC-BY-NC-ND 4.0 International license .

(sensitivity of $78.9 \%$ ). Sixteen positive patients were identified by RT-PCR only, while eleven by RT-LAMP only. Specificity was $100 \%$ for both tests, with positive RT-LAMP results presenting a characteristic banding pattern on BioAnalyzer readouts, as well as similar melting point curves analysis using Realtime PCR.

Differences between RT-PCR and RT-LAMP results are not statistically significant $(p=0.44)$ and the proportion of agreement was 0.89 . Kappa value is 0.71 .

\section{DISCUSSION}

Efforts to control SARS-CoV-2 depend on sensitive (>70\%), highly specific (>98\%), fast turnaround time diagnostic tests. (Larremore et al. 2020) In this study we describe a scalable method that is accurate, time and cost effective, and displays a sensitivity and specificity similar to the gold standard RT-qPCR. As a result, it has enormous potential in helping to identify infected individuals to control disease spread.

Several molecular detection kits have been developed for faster and more accurate detection of SARS-CoV-2 virus. As expected, sensitivity has been shown to vary according to the sample analyzed. RT-LAMP assays with viral RNA extracted from swab samples demonstrated high sensitivity ranging from 94 to $100 \%$. (https://www.fda.gov/media/138249/download) However, it is not clear if the sensitivity of RT-LAMP from nasopharyngeal swabs can be comparable to RT-LAMP using saliva specimens. Our direct RT-LAMP test from saliva samples has a lower sensitivity as compared to RT-PCR from nasopharyngeal swabs (78.9\% vs. 85.5\%), an observation also made by another saliva-direct RT-LAMP study. (Bhadra et al. 2020)

Noteworthy, some SARS-CoV-2 positive samples were only identified (and confirmed) by RT-LAMP. Considering we were testing different biological samples, this result may be attributed to the presence of the virus solely in saliva of infected patients. The comparison of different techniques, RT-LAMP and RT-PCR, in different types of biological samples is a limitation of this work. This comparison may render incongruent results due to the presence of virus in only one of these biological samples, and not represent the real 
efficiency of the methods.

The protocol described and validated here focuses on scalability and short turnaround times. Variations on this protocol, such as the addition of standard RNA extraction and concentration can be used to improve sensitivity in detriment of speed and cost. Alternatively, increase in the fluorescence detection cutoff, with removal of the dissociation curve, can be used to speed and decrease costs in detriment of sensitivity and specificity. Each variation can serve distinct purposes (screening or diagnosis), fit different geographic location socio-economic constraints, and moment of the pandemic.

In conclusion, we contribute efforts to contain the pandemic by describing and validating a scalable, fast, and low cost SARS-CoV-2 test that can be easily collected. The ease of implementation should allow this to be implemented in both developed and developing countries.

\section{REFERENCES}

Bartolone, Sarah N., Maya O. Tree, Michael J. Conway, Michael B. Chancellor, and Laura E. Lamb. 2018. "Reverse Transcription-Loop-Mediated Isothermal Amplification (RT-LAMP) Assay for Zika Virus and Housekeeping Genes in Urine, Serum, and Mosquito Samples." Journal of Visualized Experiments: JoVE, no. 139 (September). https://doi.org/10.3791/58436.

Bhadra, Sanchita, Timothy E. Riedel, Simren Lakhotia, Nicholas D. Tran, and Andrew D. Ellington. 2020. "High-Surety Isothermal Amplification and Detection of SARS-CoV-2, Including with Crude Enzymes." Cold Spring Harbor Laboratory. https://doi.org/10.1101/2020.04.13.039941.

James, Phillip, David Stoddart, Eoghan D. Harrington, John Beaulaurier, Lynn Ly, Stuart Reid, Daniel J. Turner, and Sissel Juul. n.d. "LamPORE: Rapid, Accurate and Highly Scalable Molecular Screening for SARS-CoV-2 Infection, Based on Nanopore Sequencing." https://doi.org/10.1101/2020.08.07.20161737. Joung, Julia, Alim Ladha, Makoto Saito, Nam-Gyun Kim, Ann E. Woolley, Michael Segel, Robert P. J. Barretto, et al. 2020. "Detection of SARS-CoV-2 with 
SHERLOCK One-Pot Testing." The New England Journal of Medicine,

September. https://doi.org/10.1056/NEJMc2026172.

Kurosaki, Y., N. F. Magassouba, and O. K. Oloniniyi. 2016. “... of Reverse

Transcription-Loop-Mediated Isothermal Amplification (RT-LAMP) Assay

Coupled with a Portable Device for Rapid Diagnosis of Ebola Virus Disease in ...." PLoS Neglected Tropical Diseases.

https://journals.plos.org/plosntds/article?id=10.1371/journal.pntd.000447

2 .

Lalli, Matthew A., Xuhua Chen, S. Joshua Langmade, Catrina C. Fronick,

Christopher S. Sawyer, Lauren C. Burcea, Robert S. Fulton, et al. 2020.

"Rapid and Extraction-Free Detection of SARS-CoV-2 from Saliva with

Colorimetric LAMP." medRxiv : The Preprint Server for Health Sciences,

May. https://doi.org/10.1101/2020.05.07.20093542.

Lalli, Matthew A., S. Joshua Langmade, Xuhua Chen, Catrina C. Fronick,

Christopher S. Sawyer, Lauren C. Burcea, Michael N. Wilkinson, et al.

2020. "Rapid and Extraction-Free Detection of SARS-CoV-2 from Saliva by

Colorimetric Reverse-Transcription Loop-Mediated Isothermal

Amplification." CLinical Chemistry, October.

https://doi.org/10.1093/clinchem/hvaa267.

Lamb, Laura E., Sarah N. Bartolone, Elijah Ward, and Michael B. Chancellor.

2020. "Rapid Detection of Novel Coronavirus (COVID19) by Reverse

Transcription-Loop-Mediated Isothermal Amplification.”

https://doi.org/10.2139/ssrn.3539654.

Larremore, Daniel B., Bryan Wilder, Evan Lester, Soraya Shehata, James M.

Burke, James A. Hay, Milind Tambe, Michael J. Mina, and Roy Parker. 2020.

"Test Sensitivity Is Secondary to Frequency and Turnaround Time for

COVID-19 Surveillance." medRxiv : The Preprint Server for Health

Sciences, June. https://doi.org/10.1101/2020.06.22.20136309.

Lu, Renfei, Xiuming Wu, Zhenzhou Wan, Yingxue Li, Xia Jin, and Chiyu Zhang.

2020. “A Novel Reverse Transcription Loop-Mediated Isothermal

Amplification Method for Rapid Detection of SARS-CoV-2." International

Journal of Molecular Sciences 21 (8).

https://doi.org/10.3390/ijms21082826. 
Notomi, T., H. Okayama, H. Masubuchi, T. Yonekawa, K. Watanabe, N. Amino, and

T. Hase. 2000. "Loop-Mediated Isothermal Amplification of DNA." NucLeic

Acids Research 28 (12): E63.

Poon, Leo L. M., Cynthia S. W. Leung, Kwok H. Chan, Jack H. C. Lee, Kwok Y.

Yuen, Yi Guan, and Joseph S. M. Peiris. 2005. "Detection of Human

Influenza A Viruses by Loop-Mediated Isothermal Amplification.” Journal

of CLinical Microbiology 43 (1): 427-30.

Rolando, Justin C., Erik Jue, Jacob T. Barlow, and Rustem F. Ismagilov. 2020.

"Real-Time Kinetics and High-Resolution Melt Curves in Single-Molecule

Digital LAMP to Differentiate and Study Specific and Non-Specific

Amplification." Nucleic Acids Research 48 (7): e42.

Wyllie, Anne L., John Fournier, Arnau Casanovas-Massana, Melissa Campbell,

Maria Tokuyama, Pavithra Vijayakumar, Joshua L. Warren, et al. 2020.

"Saliva or Nasopharyngeal Swab Specimens for Detection of SARS-CoV-2."

The New England Journal of Medicine 383 (13): 1283-86.

Wyllie, Anne Louise, John Fournier, Arnau Casanovas-Massana, Melissa

Campbell, Maria Tokuyama, Pavithra Vijayakumar, Bertie Geng, et al. 2020.

"Saliva Is More Sensitive for SARS-CoV-2 Detection in COVID-19 Patients

than Nasopharyngeal Swabs." Medrxiv.

https://WWw.medrxiv.org/content/10.1101/2020.04.16.20067835v1 ?fbclid=IWAR

1sexAHAFXOuDiH7_7QKParCeIcotoL2DP8OMM27uKeV0bxE8d5IZYQXvM.

Zhang, Yinhua, Nelson Odiwuor, Jin Xiong, Luo Sun, Raphael Ohuru Nyaruaba, Hongping Wei, and Nathan A. Tanner. 2020. "Rapid Molecular Detection of SARS-COV-2 (COVID-19) Virus RNA Using Colorimetric LAMP." MedRxiv. https://wWw. medrxiv.org/content/10.1101/2020.02.26.20028373v1. abstract. 
medRxiv preprint doi: https://doi.org/10.1101/2020.10.27.20220541; this version posted October 27, 2020. The copyright holder for this preprint (which was not certified by peer review) is the author/funder, who has granted medRxiv a license to display the preprint in perpetuity.

It is made available under a CC-BY-NC-ND 4.0 International license .

Table 1: RT-LAMP Mix

\begin{tabular}{|c|c|}
\hline Component & Volume $(\mu \mathrm{L})$ \\
\hline Isothermal Amplification Buffer (10x) & 5.0 \\
\hline Deoxynucleotide (dNTP) Solution Mix (10mM) & 5.6 \\
\hline dUTP (10mM) & 1.4 \\
\hline MgSO4 (100 mM) & 3.0 \\
\hline Primer mix $(10 x)$ & 3.0 \\
\hline Bst 2.0 WarmStart DNA Polymerase $(8.000 \mathrm{u} / \mathrm{ml})$ & 2.0 \\
\hline WarmStart RTx Reverse Transcriptase (15000U/ml) & 1.0 \\
\hline Uracil-DNA glycosylase (UDG) $(5000 \mathrm{U} / \mathrm{ml})$ & 1.0 \\
\hline Nuclease Free Water & 20.0 \\
\hline Saliva & 8.0 \\
\hline Total & 50.0 \\
\hline
\end{tabular}


medRxiv preprint doi: https://doi.org/10.1101/2020.10.27.20220541; this version posted October 27, 2020. The copyright holder for this preprint (which was not certified by peer review) is the author/funder, who has granted medRxiv a license to display the preprint in perpetuity.

It is made available under a CC-BY-NC-ND 4.0 International license .

Table 2: Primer Mix

\begin{tabular}{|c|c|c|c|}
\hline Volume $(\mu \mathrm{L})$ & Primer & $\begin{array}{c}\text { Initial } \\
\text { Concentration }(\mu \mathrm{M})\end{array}$ & $\begin{array}{c}\text { Final } \\
\text { Concentration } \\
(\mu \mathrm{M})\end{array}$ \\
\hline 80 & $\mathrm{FIP}(\mathrm{F} 1 \mathrm{C}+\mathrm{F} 2) \_\mathrm{RT}-\mathrm{LAMP}$ & 100 & 16 \\
\hline 80 & $\mathrm{BIP}(\mathrm{B} 1 \mathrm{C}+\mathrm{B} 2) \_\mathrm{RT}-\mathrm{LAMP}$ & 100 & 16 \\
\hline 10 & F3_RT-LAMP & 100 & 2 \\
\hline 10 & B3_RT - LAMP & 100 & 2 \\
\hline 20 & LoopF_RT-LAMP & 100 & 4 \\
\hline 20 & LoopB_RT-LAMP & 100 & 4 \\
\hline 280 & $\mathrm{H} 2 \mathrm{O}$ & - & - \\
\hline 500 & Total & & \\
\hline
\end{tabular}


medRxiv preprint doi: https://doi.org/10.1101/2020.10.27.20220541; this version posted October 27, 2020. The copyright holder for this preprint (which was not certified by peer review) is the author/funder, who has granted medRxiv a license to display the preprint in perpetuity. It is made available under a CC-BY-NC-ND 4.0 International license .

Table 3: Primer Sequences

\begin{tabular}{|c|l|}
\hline Primer & Sequence \\
\hline FIP(F1C+F2)_RT-LAMP & AGAGCAGCAGAAGTGGCACAGGTGATTGTGAAGAAGAAGAG \\
\hline BIP(B1C+B2)_RT-LAMP & TCAACCTGAAGAAGAGCAAGAACTGATTGTCCTCACTGCC \\
\hline F3_RT-LAMP & TCCAGATGAGGATGAAGAAGA \\
\hline B3_RT-LAMP & AGTCTGAACAACTGGTGTAAG \\
\hline LOOPF_RT-LAMP & CTCATATTGAGTTGATGGCTCA \\
\hline LOOPB_RT-LAMP & ACAAACTGTTGGTCAACAAGAC \\
\hline
\end{tabular}


medRxiv preprint doi: https://doi.org/10.1101/2020.10.27.20220541; this version posted October 27, 2020. The copyright holder for this preprint (which was not certified by peer review) is the author/funder, who has granted medRxiv a license to display the preprint in perpetuity. It is made available under a CC-BY-NC-ND 4.0 International license.

Table 4: Validation Results

\begin{tabular}{|c|c|c|}
\hline & RT -PCR & RT-LAMP \\
\hline Specificity & $100 \%$ & $100 \%$ \\
& $(168 / 168)$ & $(168 / 168)$ \\
\hline Sensitivity & $85.5 \%$ & $78.9 \%$ \\
& $(65 / 76)$ & $(60 / 76)$ \\
\hline PPV & $100 \%$ & $100 \%$ \\
& $(65 / 65)$ & $(60 / 60)$ \\
\hline NPV & $93.9 \%$ & $91.3 \%$ \\
& $(168 / 179)$ & $(168 / 184)$ \\
\hline
\end{tabular}


medRxiv preprint doi: https://doi.org/10.1101/2020.10.27.20220541; this version posted October 27, 2020. The copyright holder for this preprint (which was not certified by peer review) is the author/funder, who has granted medRxiv a license to display the preprint in perpetuity.

\section{It is made available under a CC-BY-NC-ND 4.0 International license .}

\section{Figure 1:}

Dissociation curves observed for positive samples in a real-time pcr equipment. These curves permit to increase the sensitivity for low viral load samples and guarantees calling of true positives, conferring higher specificity.

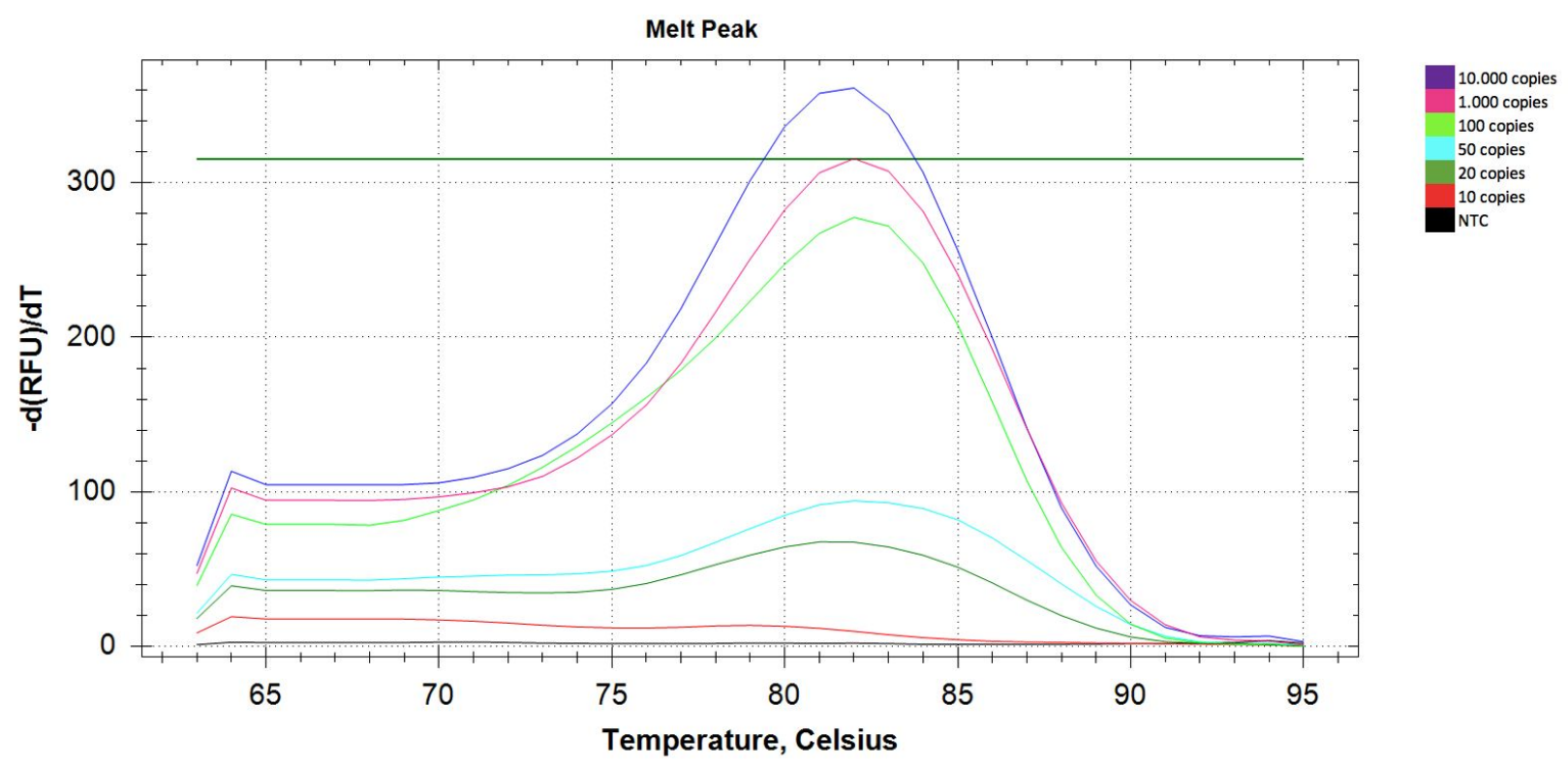

\section{Figure 2:}

Positive and negative control samples from multiple reactions show fluorescence replicability.

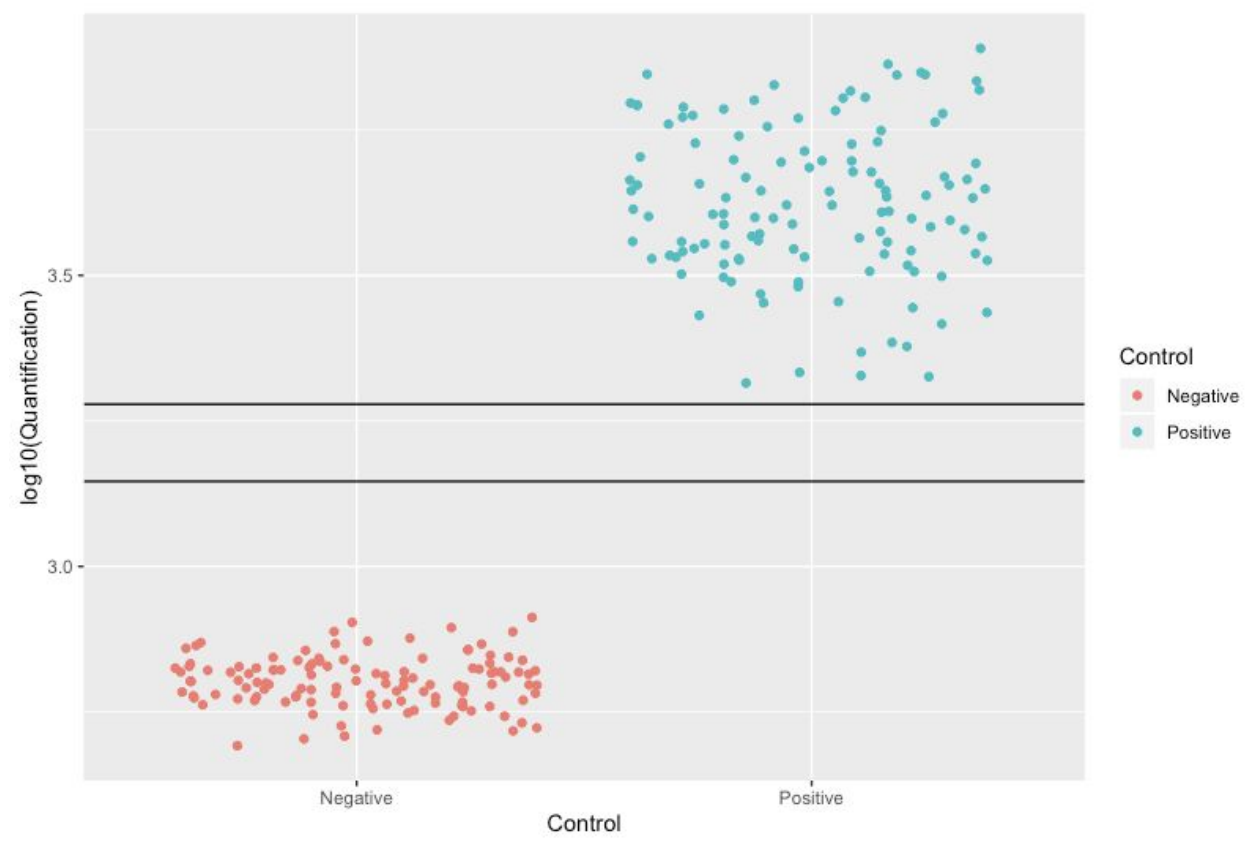


medRxiv preprint doi: https://doi.org/10.1101/2020.10.27.20220541; this version posted October 27, 2020. The copyright holder for this preprint (which was not certified by peer review) is the author/funder, who has granted medRxiv a license to display the preprint in perpetuity.

It is made available under a CC-BY-NC-ND 4.0 International license .

Figure 3:

LAMP Results Fluorescence Distribution of 50,000 consecutive saliva samples.

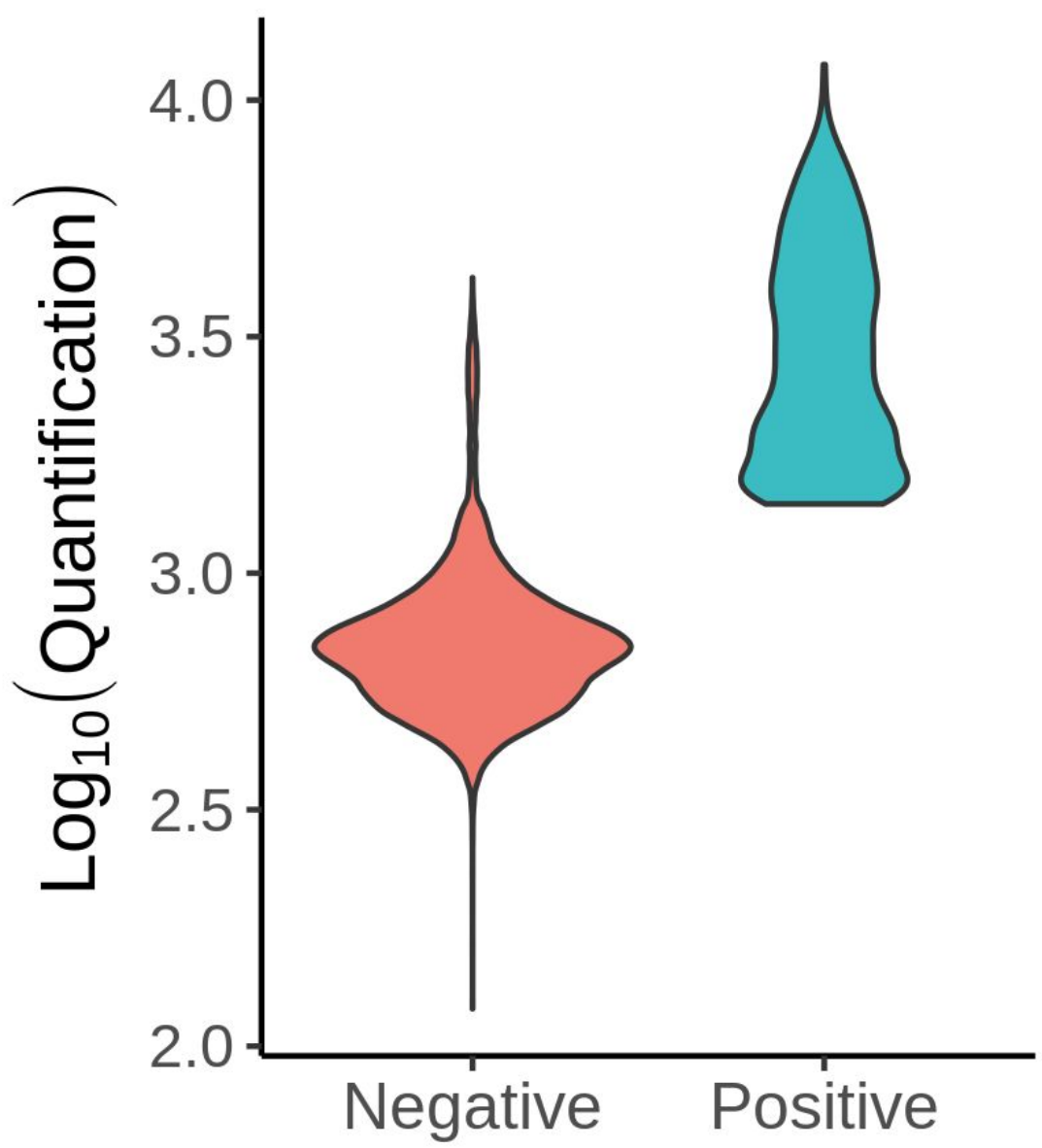

Diagnosis

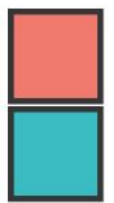

Negative

Positive 